\title{
Causes and Costs of Procurement Irregularities in Ghana's District Assemblies
}

\author{
Michael Kofi Quashie \\ School of Public Service and Governance, Ghana Institute of Management and Public Administration (GIMPA), Accra, Ghana \\ Email address: \\ kquashieus@yahoo.com \\ To cite this article: \\ Michael Kofi Quashie. Causes and Costs of Procurement Irregularities in Ghana's District Assemblies. International Journal of Law and \\ Society. Vol. 2, No. 4, 2019, pp. 58-67. doi: 10.11648/j.ijls.20190204.11
}

Received: September 16, 2019; Accepted: October 9, 2019; Published: October 26, 2019

\begin{abstract}
The Ghana government introduced procurement regulation in 2003 to govern the public procurement function in the country. However, high levels of irregularities still abound in the performance of the procurement function. The AuditorGeneral's reports for the years 2014 to 2018, revealed procurement irregularities at the country's District Assemblies. These irregularities could pose high corruption risk to the procurement process by creating fertile grounds for fraud and corruption in public procurement practice at the District Assemblies. Although articles have been written about procurement practice in Ghana, not much has been said about the practice at the district level. This article therefore seeks to fill this gap. The article throws a critical searchlight on public procurement practice at the country's District Assemblies. The methodology employed is a doctrinal one whereby the adherence or otherwise to public procurement laws of the country by the District Assemblies is looked at. The analysis of procurement practice at the assemblies has revealed that the hub of the matter facing public procurement in Ghana is the elusiveness of implementation of the tenets of the procurement regime. Having identified the weaknesses in the procurement practice, the article suggests palliatives by resorting to innovations reported in other jurisdictions to address the gap.
\end{abstract}

Keywords: Causes, Costs, Corruption, District Assemblies, Ghana, Irregularities, Public Procurement

\section{Introduction}

Ghana's Constitution requires, inter alia, that the State takes all necessary action to ensure that the national economy is managed in such a manner as to maximize the rate of economic development and to secure the maximum welfare, freedom and happiness of every person in Ghana as well as provide adequate means of livelihood and suitable employment and public assistance to the needy. [1] One of the strategies adopted by the government of Ghana to fulfill these social contract pledges to procure and deliver basic goods, works and services to the people of the country was the introduction of public procurement regulation. The public procurement law, Act 663, was passed by Ghana's Parliament in 2003. [2] Sections of Act 663 was amended by Act 914 in 2016.

The objects of Act 663 (as amended) are, inter alia, to ensure that public procurement is carried out in a nondiscriminatory and transparent manner. These safeguards are geared towards achieving value for money and transparency in the country's public procurement.

The procurement law emphasizes the objective of nondiscrimination in Ghana's procurement practice. This requires that comparable situations must not be treated differently and that different situations must not be treated in the same way unless such treatment is objectively justified. Non-discrimination also limits the opportunities for procurement entities to make discretionary decisions that could be abused in favor of a particular tenderer. This is to encourage tenderers to have confidence in the procurement process and thus motivate the best firms to participate in the competitive tender process. [3] Procurement by competitive tender is the default method for procurement of goods, works and services under Ghana's procurement law. [4] The use of this method ensures that qualified and eligible prospective tenderers will have equal opportunity to submit their tenders to the procurement entity. According to Anechiarico and Jacobs using a competitive tender method reaps the benefits of (i) lowest price, (ii) prevention of official corruption, and (iii) equal opportunities to all tenderers. [5] However, the use 
of this method delays the procurement process and is also not totally devoid of corruption. Ware et al said corruption schemes in public procurement are often similar in form, shape, nature and anatomical structure worldwide. Some of these schemes are; a) kickbacks to corrupt politicians and public official (s), who influenced the award of the contract, (b) tender rigging, a case in which competitive public tender is manipulated in a way that ensures a preselected tenderer wins the tender and (c) corrupt public officials use front or shell companies, generally in conjunction with other schemes such as kickbacks to disguise their illegal influence over contract awards for which they are formally responsible.

Transparency as one of the objectives in Ghana's procurement regulation requires publicity for public procurement opportunities, and general rules limiting the discretion of procuring entities as well as verification of the fact that the rules have been followed. [6] It also aims at preventing procurement officers from indulging in possible corrupt practice due to the abuse of their discretionary authority. Paradoxically, the flip side is that if the officers are allowed to use their discretion they may make certain decisions that might enable the entity to obtain the best procurement deal for the entity. In agreement with LambertMogiliansky and Sonin, it is preliminarily suggested here that instead of removing discretion to prevent corruption, holding officials accountable for defects in the procurement process is viewed as a more efficient way of reducing corruption. [7]

Trepte said transparency enables the availability of information to the public, the press and civil society and that it makes it more difficult to be corrupt by reducing the opportunity for extracting or receiving bribes. [8] The OECD had indicated that written records of the different stages of procurement procedure are essential to maintain transparency and to provide an audit trail of procurement decisions. [9] Appropriate records are not only required to be kept by the procurement agency but also made publicly available. DeAses opined that, a legal framework that emphasizes transparency and provides clear rules and procedures helps ensure that both the government and suppliers will follow the proper procedures, participate in true competition, and avoid corrupt practices. [10] Osei-Afoakwa argued that, although transparency and non-discriminatory objectives are significant and effective in preventing corruption in public procurement they are, however, not all cure remedy for corruption. [11] The OECD requires that transparency be balanced with other imperatives of good governance such as stringent oversight and control in order to be effective against corruption in public procurement.

This article now proceeds to direct a critical searchlight on Ghana's public procurement law and procurement practice at the country's District Assemblies from the year 2014 to 2018 and then assesses the weaknesses that resulted in procurement irregularities for the period under review. The data herein utilized is gleaned mainly from the AuditorGeneral's reports for 2014 to 2018. Although articles have been written about procurement practice in Ghana, not much has been said about the practice at the district level. This article therefore seeks to fill this gap. The article begins with a look at the concept of corruption. It then proceeds to assess the efficacy of the country's procurement laws by analyzing the Auditor-General's reports on procurement irregularities at the District Assemblies. This is followed by examination of the procurement weaknesses at the District Assemblies. The final part of the article is devoted to conclusions arrived at and recommendations made as palliatives, which could address the gaps identified by the article.

The elimination of corrupt practice in procurement is an essential pillar of public procurement laws. It is therefore important to comment on the concept of corruption, and the article now proceeds to look at this phenomenon.

\section{Corruption in Procurement Practice}

The term corruption is a very complex one and its meaning may range from moral depravity to dishonest or fraudulent conduct by those in power, and typically involves bribery. For the purposes of procurement practice the article looks at corruption from the position of a principal and agent relationship. Bardhan said corruption refers to the use of public office for private gain, where an official (the agent) entrusted with carrying out a task by the public (the principal) engages in some sort of malfeasance for private enrichment which is difficult to monitor by the principal. [12] Trepte agrees with the statement that the goal of the agent may not be to maximize social or economic welfare, the government's presumed goal, but rather to maximize his own personal benefit. Corruption and bribery are examples of deliberate exploitation for personal gain. The ability of the agent to act in his own interest is based on the fact that he holds information, which is not available to the principal. Williams-Elegbe posited that the agent may use this knowledge to his/her advantage by manipulating the procurement process. [13] Obicci, however, argued that Procurement Officers (agent) are sometimes pressured by politicians to compromise on their professionalism in favor of entities affiliated with these politicians. [14] Williams opined that corruption is an economic, political, and development inhibitor, which is responsible for costly diversion of scarce resources and an impediment to development effectiveness, because it increases the costs of economic activity thereby reducing the optimal use of resources. [15]

Hawkins and McKittrick stated that between 10-30\% of the investment in publicly funded construction projects may be lost through mismanagement and corruption. [16]Ware et al cited Transparency International's estimate that globally at least $\$ 400$ billion a year is lost to corruption through public procurement. Bawumia said that over $90 \%$ of the corruption cases reported in Ghana were related to public procurement. [17]

Ameyaw and Mensah; Oluka and Ssennoga aver that public procurement is perceived to be susceptible to corruption from project inception to completion, and that it is more prevalent at the tender evaluation stage of the 
procurement process. [18] It is particularly susceptible to corruption because of the high level of funds involved. This is further exacerbated by the relatively high degree of discretion that public officials and politicians have over public procurement programs in comparison with other areas of public expenditure. Political or high-level corruption often seeks to steer contracts to the favored tenderer without detection. This may be done in a number of ways, including avoiding competition, favoring certain tenderers by tailoring specifications or sharing insider information with them. Fazekas and David-Barret said such corruption schemes may involve bribery and transfer of large cash amounts as kickbacks. [19] Matechak, however, posits that there is the possibility of discrepancies between beliefs about corruption frequency and its actual incidence in public procurement. [20] Lindskog et al opined that it is necessary to distinguish between cases of corruption and those of inefficiency, lack of knowledge or capacity to perform the procurement function professionally. [21] Lanyi avers that corrupt transactions such as bribes, are not normally reported, and so difficult to compile data on. [22] Kaufman et al are, however, of the opinion that corruption could be measured by gathering the informed views of relevant stakeholders, tracking countries' institutional features and careful audits of specific projects. [23]

Although corruption preventive measures provide an important framework for the procurement process, strong and effective enforcement procedures are even more important. This is because problems with enforcement can lead to widespread corruption. Penalizing corrupt actors in the procurement arena requires methods for detecting corruption and a system for effectively punishing corrupt public and private sector actors. The United Nations Convention Against Corruption requires that procurement systems are put in place to address; (a) the public distribution of procurement procedures and invitations to tender, (b) conditions for participation such as selection and award criteria,(c) the use of objective and predetermined criteria for the correct application of procurement procedures,(d) a domestic review system to ensure legal recourse remedies and (e) measures to regulate procurement personnel such as screening and training. [24] Williams-Elegbe said governments could use administrative, regulatory and social tools to fight corruption in public procurement. Matechak posited that fighting corruption in public procurement requires that the procurement planning phase, budgetary and financial controls should be operationally separate and procurement requirements be subject to internal and public scrutiny. This will ensure a holistic approach to fighting the corruption canker in public procurement. Ntayi et al. said moral scripts should be utilized in reducing corruption by engaging in morally responsible behavior. [25] This could promote ethics and value for money transactions. Lindskog et al are of the view that there is the need for asset disclosure by public officials of a certain rank and the need for freedom of information laws to combat corruption. There is also the need to strengthen and review existing internal control systems for that purpose. Søreide made the point that the establishment of an independent procurement unit of professional officers together with transparent and political commitment may reduce the problem of corruption in public procurement. [26] The OECD's position is that mutually supportive principles may directly or indirectly prevent corruption and stimulate good governance in public procurement, these principles include integrity of actors, transparency, accessibility, eprocurement as well as strict oversight control. [27]

As a result of the proliferation of e-procurement in the public sector, anti-corruption agencies and watchdog organizations in many countries currently have access to a lot of information on public procurement. Gallego et al argued that this could help in anticipating which transactions may have high corruption risk. [28] Specialized training for procurement officials and procurement auditors could also be an effective way to prevent or detect procurement irregularities. The OECD indicated that there are three critical, overarching factors that underpin the procurement system, which may engender or heighten possible risks of corruption throughout the procurement chain and these are; a) budget management, b) personnel management, and c) staff capacity. [29]

\section{Procurement, Store and Contract Irregularities Contained in The Report of Ghana's Auditor-General on District Assemblies from 2014 to 2018}

The districts of Ghana are second-level administrative subdivisions of the country, below the level of regions and there are currently two hundred and sixty of them. The districts are categorized as follows; a) ordinary districts, b) municipal districts and c) metropolitan districts. The ordinary districts have a minimum population of seventy-five thousand people, municipal districts have a minimum population of ninety-five thousand people, and metropolitan districts have a minimum population of two hundred and fifty thousand people.

The districts are governed by District Assemblies, which serve as the highest political authority in each district. [30] The District Assemblies consist of: a)the District Chief Executive, appointed by the President of the Republic of Ghana, b)one person from each electoral area within the district elected by universal adult suffrage, c)the member or members of Parliament from the constituencies that fall within the area of authority of the District Assembly, and d)other members ( not exceeding thirty per cent of the total membership of the District Assembly) appointed by the President in consultation with the traditional authorities and other interest groups in the district. The government of Ghana has started the process to eventually have District Assemblies elections held along political party lines in the future. As the political and administrative authorities over the districts, the primary function of District Assemblies is to promote local economic development.

The Auditor-General is required by the country's 
Constitution, article 187 (5) to present a report on the audit of the accounts of District Assemblies for the financial year to be laid before Parliament. The Ghana Audit Service, in fulfillment of this constitutional mandate, conducted annual audit exercises at the District Assemblies for the financial years 2014 to 2018. The audits ascertained the extent of compliance with the country's procurement laws and other relevant regulations.

According to the Auditor-General the audits exposed deficiencies and weaknesses in the internal controls of the various District Assemblies arising from ineffective supervision, weak expenditure controls and non-enforcement of relevant laws, all of which contributed to recurring irregularities. The reports further stated that procurement, stores and contractual irregularities led to compliance violations resulting in the use of uncompetitive procurement method such as single- source without approval from the
Public Procurement Authority (PPA), fuel and stores not accounted for, payments for maintenance works without certification and contracts not executed to specification. The Auditor-General further stated in the audit reports that procurement irregularities had become common occurrence and that management failed to sanction the offenders involved. [31] Asenso-Boakye and Etse have opined that procurement irregularities posed high corruption risk to the procurement process since they could create fertile grounds for fraud and corruption in the country. [32] Odhiambo and Kamau aver that strict adherence to public procurement procedures is important if public funds are to be used in the best way possible. [33]

A summary of the financial cost to the country as a result of the irregularities for the five year-period, as extracted from the audit reports, is captured below;

Table 1. Cost of Procurement, Stores and Contract Irregularities.

\begin{tabular}{|c|c|c|c|c|c|c|}
\hline FUND NAME & 2014 GHs & 2015 GHs & 2016 GHs & 2017 GHs & 2018 GHs & TOTAL GHs \\
\hline District Assemblies Common Fund & $8,148,081.52$ & $27,204,883.01$ & $37,180,876.64$ & $33,661,951.02$ & $72,975,165.65$ & $179,170,957.84$ \\
\hline District Assemblies Internal Generated Fund & $2,213,744.55$ & $410,457.24$ & $163,619.57$ & $3,265,113.88$ & $2,205,561.74$ & $8,258,496.98$ \\
\hline TOTAL & $10,361,826.07$ & $27,615,340.25$ & $37,344,496.21$ & $36,927,064.90$ & $75,180,727.39$ & $187,429,454.82$ \\
\hline
\end{tabular}

From the above table, there had been procurement irregularities for the five-year period. Dza et al expressed the view that despite the promulgation of the Public Procurement Act 663 (as amended), public procurement in Ghana is still fraught with abuse such as the use of phantom vendors, false claims, and presentation of fictitious invoices for payment. [34] Through connivance between staff and suppliers, incomplete orders not meeting required specifications are accepted, with receiving slips indicating that a full order with the required specifications was delivered.

The President of the Republic of Ghana appoints District Chief Executives for every district in Ghana, with the prior approval of not less than two-thirds majority of members of the Assembly present and voting at the meeting. [35]

Dza et al. said District Assembly heads, who are representatives of the political party in government, sometimes compromise the integrity of the procurement processes at the various districts. Nuertey et al posited that the compromises are evident in the areas of selection of procurement officials, procurement process circumventions, and the choice of projects. [36] The effect of these influences include selection of poor quality suppliers, employment of poor quality procurement officials, lack of transparency in the procurement process and increase in the costs of procurement.

The Public Accounts Committee of Parliament indicated that failure to apply sanctions over the years had contributed immensely to financial violations at the assemblies. [37] The Committee therefore urged the Ministry of Finance to establish audit committees in the District Assemblies to address internal financial management weaknesses in the assemblies. The Auditor-General had as at November 2018 levied a total amount of GHs 511,211,239.04 against individuals, companies and institutions who committed financial infractions against the State for refund. [38]

Ghana's Constitution requires that a public official shall not put himself in a position where his personal interest conflicts or is likely to conflict with the performance of the functions of his office. [39] The country's Criminal Offences Act, 1960 (Act 29 of 1960, as amended) creates a miscellany of offences relating to corruption of public officials. [40] Also Act 663 (as amended) spells out punitive sanctions for offences relating to public procurement infractions. [41]

Global Integrity reported that the Ghana government's actions on audit reports appear unsatisfactory, particularly if they involve political figures and party loyalists, making the audit a mere formality. [42] According to Global Advice Network there are reports of continuing widespread abuse in the award of contracts in Ghana, particularly at the local government level. [43] Ghana's Corruption Report stated that bribes and irregular payments are often exchanged in return for obtaining government contract and licenses. [44] Public officials, who receive bribes may return the corrupt favor by restricting or eliminating open competition in procurement.

Bertelsmann Foundation avers that some of the factors fueling corruption in public procurement include a weak government administration and the state being a major investor and contractor. [45] Tenderers cannot therefore expect complete transparency in locally funded contracts, and there are allegations of corruption in the tender processes. Osei-Afoakwa opined that there is the need for possible legislative intervention and changes aimed at improving the capacity of the procurement law so as to protect the integrity of the system and to deter corruption. [46] Dza et al are of the view that to ensure equity and fairness, complete and proper accountability in public procurement, politicians and the society at large must desist from influence peddling during the procurement process so as to ensure that award of 
contracts is based on merit. [47]

The OECD said whistleblowing promotes accountability by encouraging the disclosure of information about misconduct and possible corruption, while protecting the whistleblower against retaliation. Ghana's Whistleblowers Act 2006 provides for the manner in which individuals may, in the public interest, report information that relates to unlawful or other illegal conduct or corrupt practices of others. Global Integrity, however, criticized the country for its lack of effective protection for people who chose to report incidents of corruption and also for the fact that no fund had been created as required by the law for such purpose. This situation could be a disincentive for people to report on public procurement corruption in Ghana.

\section{Procurement Weaknesses at Ghana's District Assemblies}

Procurement weaknesses at the District Assemblies could lead to corrupt practices and thus makes it difficult to achieve transparency, non-discrimination, economy, efficiency and effectiveness in public procurement.

The foremost weakness bedeviling procurement at the District Assemblies is the manipulation of and interference in the procurement process by government appointees. Nuertey et al said the government's appointees at the District Assemblies engage in political patronage through the selection of procurement officials, procurement process circumventions, giving out contracts to party cronies and the choice of projects. Dza et al observed that the major rationale for politicians influencing the procurement process is to ensure that the ruling party's members and supporters get contracts in order for them to make financial contributions to the party. This situation takes the professionalism out of procurement practice since professional code of conducts are flouted with impunity, and unethical conducts become the norm. As a result the government's attitude towards audit reports, especially if they involve political figures and party loyalists is unsatisfactory.

There is the need for government to treat the audit reports with all the seriousness they deserve by ensuring that recommendations in the audit reports are strictly complied with by the District Assemblies. There is also the need to amend Act 663 (as amended), schedule 1C to ensure that membership of the Entity Tender Committees at the District Assemblies is strengthened by including members of professional bodies with skills required in procurement on the committees. This is to ensure that every stage of the procurement activity and procedures prescribed in the procurement law have been followed at the District Assemblies as required by Act 663 (as amended), section 17. The public, media as well as civil society organizations (CSOs) could also play a critical role in this regard by monitoring and exposing government's apathy towards public procurement irregularities. Journalists need to be educated on the public procurement process so that they can understand better where potential procurement corruption might lie as well as spot them when they appear. It is hoped Ghana's right to information Act, which comes into effect in January 2020, will make it possible for the media in particular and the public in general to have reasonable access to the needed information in order to find out details about public procurement transactions. [48] The law seeks to foster a culture of transparency and accountability in public affairs and provide for related matters. The potency of many writers on procurement practice in Ghana and elsewhere to expose corrupt actions of individuals and companies through published findings so as to reduce corrupt acts cannot be underestimated. This provides an opportunity for the public to monitor the use of public funds.

Coupled with the above, the use of single-source procurement method without approval from the PPA by the District Assemblies raises cause for concern. Quashie avers that one of the glaring weaknesses in the use of the singlesource procurement method in Ghana is that there are no clear guidelines regulating its use. Because there are no clear rules for the selection of the supplier in the single-source procurement process, many prospective suppliers are discouraged from participating in that process. Such a situation is a veritable invitation for corrupt procurement practice. [49] Ameyaw et al identified the high rate of usage of non-competitive methods such as single-source procurement as one of the challenges militating against the implementation of Ghana's procurement laws. [50] Dagbanja said competition, transparency as well as restrictions on the application of single-source procurement can promote and encourage the participation of Ghanaian firms in public procurement. [51]This could enhance their capacity and competitiveness in economic activities in the country and also help attain value for money.

The requirement for the PPA to consider all matters under section 40 of Act 663 as a precondition to granting approval to procurement entities to use the single-source procurement method, was emphasized by the Fast Track High Court in Accra in the case of The Republic v Ministry of Education and Sports and others [Suit Number AP 6/2006]. [52] The PPA had granted an approval dated $31^{\text {st }}$ August, 2005 in an amount of US\$27,999,999.00 to the Ministry of Education and Sports to proceed by way of single-source procurement to purchase Supplementary Reader, Textbooks and Dictionaries for Basic/Senior Secondary Schools and Training Colleges throughout Ghana. The Fast Track High Court on $18^{\text {th }}$ October 2006 ruled that the PPA failed to consider all matters under section 40 of Act 663 before it granted the single-source approval and therefore quashed the said approval. Arrowsmith had opined that it is important to monitor the use of single-source method in order to prevent its abuse. [53] Telgen et al said the use of single-source procurement when open tendering would have been the right procedure to follow, is an example of a corrupt practice. [54]

The UNCITRAL Model Law (ML) 1994 on Procurement of Goods, Construction and Services was largely the legislative text for Ghana's public procurement legislation. 
The 1994 version of the ML required that procurement entities sought approval from a higher authority before using the single-source procurement method. The ML 2011, article 30 (5) (e) does not require procurement entities to seek approval from a higher authority before engaging in singlesource procurement, except in a case that has to do with socio-economic policies. Ghana could copy this provision from the ML 2011. This will make the District Assemblies directly responsible for the abuse of the single-source procurement method and for them to be sanctioned accordingly. The assemblies will only need to seek approval from the PPA for use of single-source procurement when it has to do with socio-economic policies of the country

Subsequent to the above, payments were made by District Assemblies for contracts, even though there were no strict compliance with the specifications contained in the agreements by vendors and contractors during the implementation of some of the contracts. The 2016 annual procurement assessments conducted by the PPA at procurement entities revealed several challenges relating to the administration of contracts by the entities. [55] These challenges can be attributed to the absence of credible arrangements for contract administration. Contract administration in most public procurement entities involved disjointed processes, which unfortunately resulted in poor supervision of contracts and compliance as well as missed opportunities for achieving value for money. The PPA stated in its 2016 annual report that it had developed a Contract Administration Manual to be used by the procurement entities. It is intriguing that the manual had up to the time of writing this article not been rolled out by the PPA for use by the District Assemblies. It is hoped that the early roll-out of the manual by the PPA for use by the assemblies will help address the challenges of poor contract administration as contained in the audit reports.

Lack of trained procurement personnel at the District Assemblies is also another weakness affecting procurement practice at the assemblies. A study by Peprah revealed that some procurement practitioners at the District Assemblies lacked the capacity both academically and professionally for the performance of their roles at the assemblies. [56] Dza et al pointed out that the blatant interference and disregard for due process in public procurement practices by politicians may be partly attributable to the seemingly low levels of expertise and professionalism of practitioners. This perceived weakness makes it easy for politicians to take advantage and exert power, influence and authority over procurement practitioners. Dza et al cited Cousins et al, who argued that practitioners with high skills level and knowledge had significant impact and control on financial performance and operational efficiency in terms of quality improvement and overall rise in confidence levels, and increased motivation to execute their responsibilities with a degree of confidence and professional authority.

Søreide said the establishment of an independent procurement unit of professional officers exercising high level of transparency and commitment may reduce the problem of corruption in public procurement. Trepte avers that blind adherence to a set of procurement rules can result in incompetent procurement, which could provide a shield for corrupt practices. The right approach is to create a cadre of procurement agents, who are well versed in the conduct of efficient and ethical procurement. Specialised training for procurement officials to become efficient and ethical in the performance of the procurement function is therefore an effective way to prevent procurement irregularities at the District Assemblies.

The PPA reported in its 2016 annual report that a capacity development policy paper, which inter alia required that each Procurement Entity would have a functional Procurement Unit that is managed by personnel who have the requisite procurement training, competencies, and adhere to an agreed Code of Ethics, informed the activities of the PPA during the year 2016. Subsequently the PPA organized specialized training programs for certain public officials to address challenges they might be facing in the application of Act 663 (as amended). However, the Authority also conceded in the same report that majority of practitioners involved in public procurement still lacked the requisite expertise, and knowledge of the law governing the practice to execute various tasks related to the public procurement process. It is expected that government will ensure that the perennial problem of late release of funds would be solved so that the PPA can expeditiously facilitate training programs for procurement practitioners in the public sector as required by Act 663 (amended), section 3 (j). This will help equip procurement practitioners with the requisite skill, knowledge and abilities to reduce procurement irregularities and thus minimize the risk of procurement related corruption.

In addition to the above, there is absence of random forensic audit of procurement activities at the various District Assemblies. Ghana could strengthen public procurement oversight through the conduct of random forensic audits. The forensic features of such audits could drive auditors to 'look behind the paper' and verify, for example, that invoices submitted by contractors are authentic. The PPA had occasionally commissioned procurement audit of the procurement entities. This raises a conflict of interest question. Should the PPA possess the competence to appoint auditors to as it were "audit itself"? Act 663 requires the Auditor-General to conduct procurement audit of public entities at the request of the PPA. [57] The author takes exception to this provision in the Act because the PPA grants approval for the use of restricted and single-source procurement to procurement entities. While this requirement for approval to be granted by the PPA may provide a guarantee that grounds stated in the Act for the use of singlesource and restricted tender procurement methods are met by the procurement entities, this provision could also provide an opportunity for the possible abuse of the methods in case the approval granted by the PPA is inappropriate. It is therefore suggested that apart from the request by the PPA, the Auditor -General should also be mandated by the procurement law to conduct the procurement audit of entities at the request of the 
public, state investigative agencies, and CSOs.

Coupled with the above, the absence of corruption minimising measures such as self- cleaning, and selective sanctioning at the District Assemblies is also a weakness for procurement practice at the District Assemblies. Selfcleaning requires that a firm that might otherwise be excluded from a public procurement because of wrongdoing in the past, should be admitted to the process because it had taken all necessary measures to ensure that the wrongdoing of the past will not occur again in future. The European Union (EU) refers to this measure as "self-cleaning" while the World Bank (WB) refers to a similar measure as Voluntary Disclosure Program (VDP). [58] Both EU and WB are Ghana's development partners so the country could borrow this measure from them. Selective sanctioning refers to a system that can receive procurement irregularities complaint, conduct an investigation, pursue prosecution, provide for mechanisms for adjudication or convictions and devise possible remedies. The introduction of the two measures could minimize the motivation for procurement irregularities at the assemblies and thus make procurement related corruption unattractive in the country.

In addition to the above, there is the absence of use of eprocurement system by the assemblies in conducting public procurement. The anti-corruption capabilities of public eprocurement, particularly the automation and audit trail capabilities can potentially increase the transparency and accountability of the government procurement process. [59] It is as a result of this that the Ghana government on April 30, 2019 launched a new \$5million electronic Public Procurement Portal as part of efforts to fight corruption in public procurement. [60] The e-procurement tool is to be rolled- out for use by the public procurement entities in phases. Kerali said Ghana can save more than $\$ 100$ million, an equivalent of two per cent of its gross domestic product annually, by introducing the e-procurement system. [61] However, for an e-procurement system to be effective in Ghana, there is the need for the government to expand ICT services, guarantee a secure online environment, develop standards and processes, provide constant power supply, and most importantly train procurement practitioners on how to use the tool. [62]

Coupled with the above, non-enforcement of procurement regulations at the District Assemblies is also another weakness that needs to be addressed by the government. According to the Auditor-General, procurement irregularities have become a common occurrence in Ghana's public procurement. [63] Effective enforcement of the procurement regime could begin with the government's appointment of independent investigators, who should have authority to look at present and future public procurement contracts for possible irregularities. The PPA could call for the establishment of Due Diligence and Compliance Units in all the District Assemblies to undertake such a function. This measure will help monitor public procurement practice and ensure strict compliance with Act 663 (as amended) by the assemblies. This could subsequently serve as a deterrent to corruption in public procurement.

Another factor hampering effective procurement practice at the District Assemblies is poor supervision of the procurement function. This is because management personnel are either involved in the procurement irregularities or refuse to sanction those involved. The management personnel at the District Assemblies, who do not exercise effective supervision in the performance of the procurement function, should be sanctioned for infraction of the procurement law to serve as a deterrent to others. Act 663 (as amended) has a provision for punitive sanctions for offences relating to infractions of the procurement law and this must be applied when necessary.

The Lack of integrity in undertaking the performance of the procurement function at the District assemblies is another weakness. The introduction of an Integrity pact, which was developed by Transparency International in the mid-1990's, in procurement practice at the assemblies could cure this weakness. [64] An integrity pact contains rights and obligations to the effect that neither side to a tender process will pay, offer, demand or accept bribes of any sort, or collude with competitors to obtain the contract, or while carrying it out. Also the OECD has developed best practices guidance to reinforce integrity and public trust in how public funds are managed and Ghana could borrow from this. [65] Ghana's Criminal Offences Act, 1960 (Act 29, as amended), section 240 provides explanation as to corruption by a public officer while section 241 provides explanation as to corruption of a public officer.

Dye and Stapenhurst cited Seushi's notion of "national integrity system", which required that policy responses to risk of corruption should typically involve the following pillars; political will, administrative reforms, 'watchdog' agencies (for example, anti-corruption commissions, supreme audit institutions, ombudsman), parliament, public awareness, the judiciary, the media and the private sector. [66] The author agrees with Seushi that if any of these "integrity pillars" weakens, an increased load is thrown to the others. The general equilibrium of the pillars is therefore important. Ghana's government needs to keep the 'integrity pillars' in balance in order to fight corruption in public procurement. If this is not done, the country's procurement regulation will be at best a politically astute statement of intention, which will achieve little in fighting corruption in the country's public procurement. The minimization of corruption will also require a long-lasting and credible reform of the executive, legislative and judicial organs of state that surround the procurement system and upon which a properly functioning system depends for its viability. [67] Ghana's legal and administrative system therefore needs to generate credible threats of detection and enforcement of procurement regulations. The country could also employ supply-side interventions and demand- side mechanisms to reduce the risk of procurement corruption. Supply-side interventions are measures the government can adopt to improve internal processes such as e-procurement, forensic audits, selective sanctioning and self-cleaning. Demand -side 
mechanisms should be designed to complement and strengthen these interventions, some of these could be external monitoring by CSOs, use of integrity pact, reporting and access to information sharing.

The following is a summary of the procurement weaknesses at Ghana's District Assemblies.

i. Political interference in the procurement process and government's apathy towards audit reports on procurement irregularities.

ii. The use of single-source procurement method without approval from the PPA by the District Assemblies.

iii. Poor contract administration.

iv. Lack of procurement personnel with requisite knowledge, skill and abilities required to perform the procurement function professionally.

v. Absence of random forensic audit of the procurement activities at the various District Assemblies.

vi. Absence of corruption risk minimising measures such as self- cleaning and selective sanctioning at the District Assemblies.

vii. Absence of use of e-procurement system by the assemblies for conducting the procurement function.

viii. Non enforcement of procurement regulations by the District Assemblies.

ix. Poor supervision of the procurement function.

$x$. Lack of integrity in undertaking the procurement function at the assemblies.

From the above summary, it is obvious that corruption and corrupt practices are the major factors impeding public procurement practice at the District Assemblies. It confirms Bardhan's position that there is corruption when the agent's goal is not to maximize social or economic welfare as required by the principal's presumed goal, but rather to maximize his own personal benefit. The situation also reinforces Obicci's argument that Procurement Officers (agent) are sometimes pressured by politicians to compromise on their professionalism in favor of entities affiliated with these politicians.

\section{Conclusions and Recommendations}

Corruption in public procurement is exceptionally bad and abhorrent. It has also been described as being awful not only because of its negative consequences but because it is inherently wrong, unethical, immoral and above all an illegality.[68] It distorts public finance and impairs the delivery of public services, such as the building of schools, roads and the provision and quality of medical care. The officials involved in procurement irregularities use their control over the procurement process to sometimes extract bribes from contractors, who are willing to participate in the corruption scheme.

The innovations suggested in this article as palliatives for procurement irregularities are; i) the need for government to treat audit reports with all the seriousness they deserve by ensuring that recommendations in the reports are strictly complied with by the District Assemblies. The public, CSOs and the media will also have to monitor and expose government's apathy to public procurement irregularities. There is also the need to amend Act 663 (as amended), schedule 1C (section 20) to ensure that membership of the Entity Tender Committees at the District Assemblies are strengthened by including members of professional bodies, with skills required in procurement, on the committees as is the position in schedule 1B (1), (2), (3) of Act 663 (as amended). ii) District Assemblies should be made to be directly responsible for the use of single-source method and to face the applicable sanctions in case of abuse in the use of the method. Act 663 (as amended) should be further amended such that District Assemblies will only seek approval from the PPA before engaging in single-source procurement in a case that has to do with the socio-economic policy of the country. iii)there is need for the urgent roll-out by the PPA of Contract Administration Manual for use by the procurement entities, iv)PPA should facilitate specialised training for procurement officials to become efficient and ethical in the performance of the procurement function at the District Assemblies, v)need for the conduct of random forensic audit at the District Assemblies, and that the law be amended to require the Auditor-General to conduct procurement audit of the procurement entities not only at the request of the PPA, but also when requested by the public, state investigative agencies or CSOs vi) the introduction of corruption minimising measures such as self- cleaning and selective sanctioning at the District Assemblies, vii)introduction of use of e-procurement system by the assemblies in conducting public procurement, viii) effective enforcement of the procurement regime by the establishment of Due diligence and Compliance Units in all the District Assemblies, ix)ensure effective supervision of the procurement function at the District Assemblies by sanctioning management for irregularities in the procurement process, $x$ )the introduction of an integrity pact, to ensure integrity in the performance of the procurement function at the District Assemblies as well as the need for Ghana to borrow from the OECD's developed best practices guidance to reinforce integrity and public trust in how public funds are managed.

Corruption is an insidious plague that has a wide range of corrosive effects on countries, and Ghana is not immune to this plague. This may lead to corrupt officials plundering the national wealth, which could result in a situation, where a country's badly needed resources for the needed development of the country may benefit only the corrupt few in the society. Ghana ratified the United Nations Convention against Corruption on $27^{\text {th }}$ June, 2007 and the African Union Convention on Preventing and Combating Corruption on $13^{\text {th }}$ June, 2007. The writer is not aware that Ghana has domesticated these conventions into laws. Be that as it may, the government of Ghana needs to pursue the aim of making corruption unattractive in the country by exacting a high price for it. This will free the country's badly needed resources from being plundered by the corrupt few so as to enable the government meet the social obligation of ensuring the maximum welfare of her citizens 
as required by the country's 1992 Constitution. Ghana has no option other than to take up the fight against corruption, including those that affect public procurement, with all the seriousness it deserves.

\section{References}

[1] The Constitution of the Republic of Ghana (1992), article 36 (1).

[2] Public Procurement Act, 2003 (Act 663)

[3] Ware, G., Moss, S., Campos, E. and Noone, G. (2007) Corruption in Public Procurement: A Perennial Challenge Chapter. 9 in E. Campos and S. Pradhan (Eds.) The Many Faces of Corruption (Washington DC: World Bank). pp 295-331.

[4] Public Procurement Act, 2003 (Act 663) section 35.

[5] Anechiarico, F., and Jacobs, J. (1996) The Pursuit of Absolute Integrity: How Corruption Control Makes Government Ineffective (Chicago: University of Chicago Press), Chapter 8. p 124.

[6] Public Procurement Act, 2003 (Act 663), section 3 (d).

[7] Lambert-Mogiliansky, A., and Sonin, K. (2006) Collusive Market-Sharing and Corruption in Procurement. Journal of Economics and Management Strategy, 15 (4), pp. 883-908.

[8] Trepte, P. (2005) Transparency and Accountability as Tools for Promoting Integrity and Preventing Corruption in Procurement: Possibilities and Limitations. OECD Expert Group meeting on Integrity in Public Procurement. GOV/PGC/ETH (2005)1. pp 2-35.

[9] OECD, (2007) Integrity in Public Procurement: Good Practice from A to Z', Chapter IV. Ensuring Accountability and Control in Public Procurement, pp 89-120.

[10] De Ases, A., (2005) Developing Countries: Increasing Transparency and other methods of Eliminating Corruption in the Public Procurement. Process. Public Contract Law Journal, 34 (3), pp. 553-572.

[11] Osei- Afoakwa, K., (2014) How Relevant is the Principle of Transparency in Public Procurement. Developing Country Studies (IISTE) 4 (6).

[12] Bardhan, P. (1997). Corruption and Development: A Review of Issues. Journal of Economic Literature XXXV, pp. 13201346.

[13] Williams-Elegbe, S. (2013). A Perspective on Corruption and Public Procurement in Africa: Chapter 14 in S. Arrowsmith and G. Quinot (Eds.) Public Procurement Regulation in Africa, (Cambridge University Press) pp. 336-369.

[14] Obicci, P. (2015) Conflict of Interest on Public Procurement Management in Uganda. International Research Journal of Business Management, VII, p. 52.

[15] Williams, S. (2007) The Debarment of Corrupt Contractors from World Bank-Financed Contracts. Public Contract Law Journal, 36 (3), pp 277-306.

[16] Hawkins, J., and McKittrick, B., (2012) Construction Sector Transparency Initiative: making construction more accountable. Proceedings of the Institution of Civil Engineers-
Civil Engineering. 165 (2), pp. 82-88.

[17] Nunoo, C. (2018) Bawumia Bemoans Corruption in Public Procurement. GRAPHIC ONLINE, graphic.com.gh 10.25.

[18] Ameyaw, C., and Mensah, S. (2013) Curbing Corruption in the Public Procurement Process in Ghana. Public Policy and Administration Research, 3, (5) pp. 44-53; Oluka, N. and Ssennoga, F. (2008) $3^{\text {rd }}$ International Public Procurement Conference, Amsterdam, the Netherlands.

[19] Fazekas, M., and David-Barret, E., (2015) Corruption Risks in UK Public Procurement, Government Transparency Institute. Budapest Hungary.

[20] Matechak, J., (no date) Fighting Corruption in Public Procurement. Center for International Private Enterprise.www.CIPE.ORG.

[21] Lindskog, H., Berge, S. and Olof Brehmer, P. (2010) Corruption in Public Procurement and Private Sector Purchasing Journal Of Organizational Transformation and Social Change 7 (2).

[22] Lanyi, A. (2004) Measuring the Economic Impact of Corruption. The Iris Discussion Papers on Institutions \& Development, Paper 04/06, pp. 1-20.

[23] Kaufman, D., Kray, A., and Mastruzzi, M. (2007) Measuring Corruption: Myths and Realities. Africa Region Findings \& Good Practice Infobriefs; no. 273. World Bank, Washington.

[24] United Nations Convention against Corruption. 2004. UNITED NATIONS Office on Drugs and Crime.

[25] Ntayi, J., Ngoboka, P., and Kakooza, C. (2013) Moral Schemas and Corruption in Ugandan Public Procurement. Journal of Business Ethics, 112 (3), pp. 417-436.

[26] Søreide, T. (2002) Corruption in Public Procurement. Causes, Consequences and Cures. Report- Chr. Michelsen Institute, pp1-50.

[27] OECD, (2016) Preventing Corruption in Public Procurement.

[28] Gallego, J., Rivero, G. and. Martinez, J. (2018) Preventing rather than Punishing: An early Warning Model of Malfeasance in Public Procurement. Universidad del Rosario. Facultad de Economia. Serie Documentos De Trabajo No. 222.

[29] OECD, (no date). Guidelines for Fighting Bid Rigging in Public Procurement-Helping Governments Obtain Best Value for Money

[30] The Constitution of the Republic of Ghana (1992), article 241 (3).

[31] Report of the Auditor-General on the Accounts of District Assemblies for the Financial Year Ended 31 December 2018.www.ghaudit.org Ghana Audit Service 2019.

[32] Asenso-Boakye, M., and Etse, D. (2014) Irregularities in Ghana's Public Sector Procurement and their Possible Rein forcers: A Study of The Auditor-General's Report. International Journal of Economics, Commerce and Management. 2 (2).

[33] Odhiambo, W., and Kamau, P. (2003) Public Procurement: Lessons from Kenya, Tanzania and Uganda: $O E C D$ Development Centre. Working Paper No. 208. DEV/DOC. 
[34] Dza, M., Kyeremeh, E., Dzandu, S., and Affran, S. (2018) Corruption in Public Procurement in Ghana; societal norm or deviant behavior? Archives of Business Research, 6 (12), pp. 55-66.

[35] The Constitution of the Republic of Ghana (1992), article 243.

[36] Nuertey, E., Owusu-Bempah, G., Abbey, W. and Akrofi, T. (2018) Examining the effects of Political Influences on the Procurement Functions of District Assemblies in Ghana. International Journal of Political Science, Law and International relations. 8 (3), pp. 1-10.

[37] Ghana's Parliamentary Public Accounts Committee was established by Standing Order 15 (2) of Parliament. The Committee is required to investigate and monitor the adherence of public entities to rules governing public expenditure.

[38] Special Audit Report of the Auditor-General on Disallowance and Surcharge as at 30, November 2018.www.ghaudit.org Ghana Audit Service 2019.

[39] The Constitution of the Republic of Ghana (1992), article 284.

[40] The Criminal Offences Act, 1960 (Act 29 as amended).

[41] Public Procurement Act, 2003 (Act 663), section 92.

[42] Global Integrity, 2011.

[43] Global Advice Network 2013.www.development aid.org.

[44] Ghana Corruption Report 2015-2016.www.ganintegrity.com.

[45] Bertelsmann Stiftung, BTI (2016)-Ghana Country Report. Gütersloh: Bertelsman Stiftung, 2016. http://www.btiproject.org.

[46] Osei-Afoakwa, K. (2013) The Antecedents of the Prospects of Public Procurement Regulations in Ghana, Developing Country Studies 3 (1).

[47] Dza, M., Gap, R., and Fisher, R. (2015) Taking the Professionalism out of the Profession: A Study of Procurement and Africa. International Journal of Procurement Management, 8 (3), pp 251-270.

[48] Dapatem, D. (2019) Prez Assents to RTI Act. Daily Graphic. May, 22. pp. 01, 03, 20. www.graphic.com.gh.

[49] Quashie, M. (2017) An Appraisal of Single-Source Procurement in Ghana. Journal of Law, Policy and Globalization Vol. 68 pp. 112-128.

[50] Ameyaw, C., Mensah, S. and Osei-Tutu, E. (2012) Public Procurement in Ghana: The Implementation Challenges to the Public Procurement Act. International Journal of Construction Supply Chain Management, 2 (2) pp 55-65.

[51] Dagbanja, N. D. (2014). Promoting a Competitive Local Business Community in Ghana: The Role of the Legal Framework for Public Procurement. Journal of African Law, 58, doi: 10.1017/S0021855314000084. pp 350-375.

[52] The Republic v Ministry of Education and Sports and others [Suit Number AP 6/2006]
[53] Arrowsmith, S., Treumer, J., Fejo, L. Jiang. (2010) Public Procurement Regulation: An introduction, chapter 2: Methods of procurement for goods and construction'. pp. 44-45.

[54] Telgen, J., Van der Krift, J., and Wake, A. (2016) Public Procurement Reform: Assessing Interventions aimed at Improving Transparency. London: DFID pp 4-5.

[55] Public Procurement Authority 2016 Annual Report.

[56] Peprah, J. A. (2015) Trajectories of Maverick Buying in the District Assemblies in Ghana. European Journal of Logistics, Purchasing and Supply Management, 3 (4).

[57] Public Procurement Act, 2003 (Act 663), section 91 (2).

[58] Arrowsmith, S. Priess, H., and Friton, P. (2009) Self-cleaning as a defense to exclusions for misconduct: an emerging concept in EC public procurement law? Public Procurement Law Review, 6, pp 257-282; 2014 European Union (EU) Directive, article 57; See World Bank, VDP Guidelines for Participants, para. 3.

[59] Neupane, A., Soar, J., Vaidya, K., and Yong, J. (2012) Role of Public E-Procurement Technology to Reduce Corruption in Government Procurement. International Public Procurement Conference, August 17-19, Seattle, Washington.

[60] Appiah-Adjei, S. (2019) Veep launches National Eprocurement System. GRAPHIC ONLINE, May 1, 9. 51.

[61] Appiah-Adjei, S. (2019) E-procurement can save Ghana $\$ 100 \mathrm{~m}$ yearly-World Bank. Daily Graphic, May 3, p16 www.graphic.com.gh.

[62] Editorial. (2019). E-Procurement, Another Plus. Daily Graphic, May, 3, p7 www.graphic.com.gh.

[63] Report of the Auditor-General on the Management and Utilization of District Assemblies' Common Fund and Other Statutory Funds for the Financial Year Ended 31 December 2018.www.ghaudit.org. Ghana Audit Service 2019.

[64] Kostyo, K. (2006) (ed), Handbook for Curbing Corruption in Public Procurement. Transparency International (section 3. 1 entitled 'The TI Integrity Pact'), pp. 80-89.

[65] OECD, (2013) Implementing the OECD Principles for integrity in Public Procurement: Progress since 2008.

[66] Seushi, I., President of Transparency International-Tanzania, as cited by Dye, K., and Stapenhurst, R. (1998) Pillars of Integrity: The Importance of Supreme Audit Institutions in Curbing Corruption. The Economic Development Institute of the World Bank 111.

[67] Linarreli, J., (1998) Corruption in Developing Countries and Economies on Transition: Economic and Legal Perspectives', Chapter. 7 in Arrowsmith, S., and Davies, A. (Eds.), Public Procurement Global Revolution (London: Kluwer Law International).

[68] Osei-Afoakwa, K. (2012) What Makes Corruption in The Public Procurement Process Awful? International Journal of Development and Sustainability. 1 (3) (In Press). 